\title{
Possible Associations of Vitamin D, Vitamin D-Binding Protein, and Vitamin D Receptor with Diabetic Neuropathic Pain and Balance [Letter]
}

This article was published in the following Dove Press journal: Journal of Pain Research

\author{
Asuman Celikbilek (D) \\ Department of Neurology, Kudret \\ International Hospital, Ankara, Turkey
}

Correspondence: Asuman Celikbilek Kudret International Hospital,

Department of Neurology, Ankara 06600, Turkey

Tel +905056532615

Fax +903122299868

Email asunebioglu@yahoo.com

\section{Dear editor}

We read with great interest the article recently published in Journal of Pain Research by Sari et al, ${ }^{1}$ examining the effect of vitamin D replacement therapy on neuropathic pain and imbalance in patients with diabetic neuropathy (DN). They found that vitamin D replacement reduced neuropathic pain and improved balance scores in patients with DN. They suggested that a vitamin D replacement schedule might be planned in diabetic patients with vitamin $\mathrm{D}$ deficiency in order to resolve neuropathic pain and balance problems. However, we would like to add some points which may be taken into consideration.

We have also published a study showing the decreased serum vitamin D levels in patients with DN. ${ }^{2}$ In agreement with the study by Sari et al, vitamin D deficiency was more common in diabetics with distal symmetrical polyneuropathy. This may be explained by the neurotrophic effects of vitamin D on nerve function. ${ }^{1}$ However, another explanation might be the nociceptor repair function for vitamin $\mathrm{D}$, which elevates the pain threshold. ${ }^{3}$ Differently, we investigated the serum levels of vitamin D-binding protein (VDBP) and vitamin D receptor (VDR) as well. VDBP, secreted by the liver, is essential for vitamin D metabolism. It functions as a specific transporter of circulating vitamin D metabolites, including 25-hydroxy vitamin D (circulating reservoir) and 1,25-hydroxy vitamin D (active form). ${ }^{2}$ It has been suggested that the different VDBP variants bind the diverse vitamin D metabolites with varying affinity, thereby affecting the amount of intracellular vitamin $\mathrm{D}$ in beta cells. ${ }^{4}$ Additionally, activated vitamin $\mathrm{D}$ functions by binding to a nuclear receptor, the VDR. Data have demonstrated that VDR is expressed in many tissues, including those involved in the regulation of glucose metabolism, such as muscle-in association with balance- and pancreatic beta cells. ${ }^{4}$ In our study, we found the serum VDBP and VDR levels similar in patients with DN compared with those without $\mathrm{DN}^{2}$ This may be explained that vitamin $\mathrm{D}$ influences a broader range of metabolic systems by complex signaling pathways via both genomic and nongenomic courses outside the cell nucleus. ${ }^{4}$

Taken together, it seems that vitamin D, VDBP and VDR share complex mechanisms in the development of DN. In this respect, levels of VDBP and VDR at baseline and after vitamin D supplementation may give insight to evaluate the contributions of these proteins in the management of $\mathrm{DN}$. 


\section{Disclosure}

The author reports no conflicts of interest in this communication.

\section{References}

1. Sari A, Akdoğan AZ, Arifoglu CK, Bilir BY, Durmus B. Does vitamin $\mathrm{D}$ affect diabetic neuropathic pain and balance? $J$ Pain Res. 2020;13:171-179. doi:10.2147/JPR.S203176
2. Celikbilek A, Gocmen AY, Tanik N, et al. Decreased serum vitamin D levels are associated with diabetic peripheral neuropathy in a rural area of Turkey. Acta Neurol Belg. 2015;115(1):47-52. doi:10.1007/ s13760-014-0304-0

3. Yong WC, Sanguankeo A, Upala S. Effect of vitamin D supplementation in chronic widespread pain: a systematic review and meta-analysis. Clin Rheumatol. 2017;36(12):2825-2833. doi:10.1007/s10067-017-3754-y

4. Fawzy MS, Beladi FIA. Association of circulating vitamin D, VDBP, and vitamin D receptor expression with severity of diabetic nephropathy in a group of Saudi type 2 diabetes mellitus patients. Clin Lab. 2018;64(10):1623-1633. doi:10.7754/Clin.Lab.2018.180401

Dove Medical Press encourages responsible, free and frank academic debate. The content of the Journal of Pain Research 'letters to the editor' section does not necessarily represent the views of Dove Medical Press, its officers, agents, employees, related entities or the Journal of Pain Research editors. While all reasonable steps have been taken to confirm the content of each letter, Dove Medical Press accepts no liability in respect of the content of any letter, nor is it responsible for the content and accuracy of any letter to the editor

Journal of Pain Research

Dovepress

\section{Publish your work in this journal}

The Journal of Pain Research is an international, peer reviewed, open access, online journal that welcomes laboratory and clinical findings in the fields of pain research and the prevention and management of pain. Original research, reviews, symposium reports, hypothesis formation and commentaries are all considered for publication. The manuscript management system is completely online and includes a very quick and fair peer-review system, which is all easy to use. Visit http:// www.dovepress.com/testimonials.php to read real quotes from published authors. 